\title{
Can stress turn trees hair white? Hair covering of stems improves resilience of corticular photosynthesis against heat-stress
}

\author{
Christiane Wittmann $(\mathbb{D} \cdot$ Barbara Kelsch $\cdot$ Franziska Reßing $\cdot$ Hardy Pfanz
}

Received: 4 January 2021 / Accepted: 2 April 2021/Published online: 13 April 2021

(C) The Author(s) 2021

\begin{abstract}
The hypothesis was tested that hair covering of stems improves resilience of corticular photosynthesis against heat stress. Hairy and nonhairy outer bark of Quercus ilex L. and Quercus robur L. trees was removed and optical properties measured. Additionally, structural bark traits and chlorophyll fluorescence parameters during heat stress treatment were studied. Optical analysis revealed a protective role of hairy outer bark (OB) against overheating of the underlying cortex of the stems. Hairiness decreased OB transmittance and increased thermal insulation of stems by an increased absorptance and reflectance of OB in the visible (380-720 nm) and an increased reflectance in the infrared part of the spectrum (720-900 nm). Simple linear regression analysis revealed no significant effect of stem structural traits (OB thickness (OBT), cortex density $\left(\mathrm{D}_{\text {cortex }}\right)$, cortex water content $\left.\left(\mathrm{W}_{\text {cortex }}\right)\right)$ on corticular photochemistry $\left(\mathrm{PS}_{\mathrm{cort}}\right)$, while optical traits of outer bark were significantly $(\mathrm{P}<0.01)$ correlated with PS $_{\text {cort }}$ OB reflectance explained up to $91 \%$ of the variation in PSII quantum yield under heat stress. At high temperatures $\left(>45^{\circ} \mathrm{C}\right) \mathrm{PS}_{\text {cort }}$ of the hairy species showed a higher resilience and a better post-stressrecovery as compared to the non-hairy one. It is concluded that stem hairs play a physiologically
\end{abstract}

C. Wittmann $(\bowtie) \cdot$ B. Kelsch · F. Reßing $\cdot$ H. Pfanz Department of Applied Botany and Volcano Biology, University of Duisburg-Essen, 45117 Essen, Germany e-mail: christiane.wittmann@uni-due.de significant role in modulating the stem energy balance due to a close interaction between optical characteristics of hairy $\mathrm{OB}$ and stem photochemical processes.

Keywords Corticular photosynthesis - Heat stress Resilience $\cdot$ Pubescence $\cdot$ Hairs · Optical analysis

\section{Introduction}

In a warming world, the number and intensity of heat waves have increased and this trend is expected to continue through the twenty-first century (Yao et al. 2013; Teskey et al. 2015). Heatwaves may impair tree function and forest C uptake (Drake et al. 2017) and significantly reduced tree photosynthesis and growth (Marchand et al. 2005, 2006; Bauweraerts et al. 2014). Extreme heat-stress may lead to direct thermal damage or even death of plants (O'Sullivan et al. 2017). Above the thermal threshold, leaf photosynthesis declines and the production of reactive oxygen species (ROS) and thus photo-oxidative stress increases (Wahid et al. 2007; Teskey et al. 2015). Furthermore, heat-stress responses at the cellular-level of leaves are inhibitory effects on photosystem II (PSII) photochemistry and electron transport, amplification of thylakoid membrane fluidity, and the induction of heat-shock protein expression (Wahid et al. 2007; Teskey et al. 2015). In trees, the response of leaf photosynthesis to high 
temperatures has received more attention than responses of other physiological processes (Teskey et al. 2015), which reflects its importance as well as its sensitivity to heat (Berry and Bjorkman 1980; Salvucci and Crafts-Brandner 2004). The response of stem photosynthesis or corticular photosynthesis (Wittmann et al. 2006; Berveiller et al. 2007; Ávila et al. 2014) to high temperatures is uncertain, but might be also important for tree function.

Chlorophyll-containing cells in the cortex of shrub and tree species are able to refix a substantial portion of $\mathrm{CO}_{2}$ produced through respiration by the underlying tissues or carried into the stem segment by the transpiration stream (Pfanz et al. 2002; Teskey et al. 2008; Ávila et al. 2014; Cernusak and Cheesman 2015). This, so-called corticular photosynthesis, allows young stems to compensate for $60-90 \%$ of their respiratory carbon loss (Pfanz et al. 2002; Wittmann et al. 2006; Wittmann and Pfanz 2007; Berveiller et al. 2007) and equals growth respiration on an annual basis (Damesin 2003). Tracer studies by Powers and Marshall (2011) and Bloemen et al. (2013) further showed, that ${ }^{13} \mathrm{C}$-labelled $\mathrm{CO}_{2}$ added to the xylem stream of temperate tree species is transported up towards the canopy, and finally emitted to the atmosphere via leaf stomata. A certain fraction is refixed in photosynthetic tissues in branches and petioles. Hence, recycling of $\mathrm{CO}_{2}$ within trees is potentially important for the carbon economy of trees.

However, up to now we have almost no information regarding the impact of high temperatures on corticular photosynthesis. Only one study by Wittmann and Pfanz (2007) on the temperature response of stems of beech and birch seedlings reported that corticular photochemical yield followed the same temperature pattern as corticular $\mathrm{CO}_{2}$ assimilation. The maximum quantum yield of PSII $\left(\mathrm{F}_{\mathrm{v}} / \mathrm{F}_{\mathrm{m}}\right)$ decreased drastically at freezing temperatures $\left(-5^{\circ} \mathrm{C}\right)$, while from 30 to $40{ }^{\circ} \mathrm{C}$ only a marginal decrease in $\mathrm{F}_{\mathrm{v}} / \mathrm{F}_{\mathrm{m}}$ was found (Wittmann and Pfanz 2007).

Furthermore, we assume that hairiness is a trait that could serve a role in reducing photoinhibition and heat loading in tree stems under heat stress. Leaf trichomes were found to influence other biophysical processes, such as light reflectance (e.g. Ehleringer et al. 1976) and convective heat loss (e.g. Meinzer and Goldstein 1985). Increased reflectance of light from the surface of hairy leaves decreased absorption of light energy and had profound consequences for leaf functionality
(Skelton et al. 2012). For example, leaf pubescence reduced photoinhibition in several species occurring in high light environments (e.g. Skaltsa et al. 1994). Accordingly, stem hairs can be expected to have both direct and indirect effects on physiological stem processes.

Here, we provide the first analysis of how hair covering of stems of woody trees interact with stem optical characteristics and influences corticular photochemistry under heat stress. Our hypothesis was tested on a Mediterranean oak species (Quercus ilex L.) with hairy stems compared to a temperate European oak species with non-hairy stems (Quercus robur L.). Tree saplings of both species were grown outside in the Botanical Garden of the University of DuisburgEssen. We exposed current-year stems of both species in a climate chamber to increasing temperatures of up to $45{ }^{\circ} \mathrm{C}$ and monitored physiological responses and recovery from heat stress using chlorophyll fluorescence. Our physiological understanding of plant recovery following an extreme stress event is limited. Even the potential of leaves to recover after enduring short episodes of heat stress is considerably understudied (Curtis et al. 2014). Here, Chlorophyll- $a$ Fluorometry was used to determine high temperature response and post-stress recovery of corticular photosynthesis. Furthermore, we tested the hypothesis that oak species from warmer environments might have a higher resilience of corticular photosynthesis against heat-stress. By relating bark optical and structural properties to corticular photosynthesis our study also provides insight into how bark properties, stem physiological processes and post-stress recovery may interact under high temperature stress.

\section{Materials and methods}

\subsection{Plant material}

The study was conducted in July 2017 on 5-years-old holm oak (Quercus robur L.) and common oak trees (Quercus ilex L.) grown outside in the Botanical Garden of the University Duisburg-Essen (Decimal degrees (DD): latitude 51.43, longitude 6.98; altitude above sea level: $103 \mathrm{~m}$ ), Germany). Quercus ilex L. (holm oak) is a sclerophyllous, evergreen tree widely distributed over the Mediterranean region. It grows in Mediterranean-continental areas, always under 
climatic conditions marked by dry and hot summers (Peñuelas and Llusià 2002).In these areas heat tolerance has great importance, as temperature can rise up to $45-50{ }^{\circ} \mathrm{C}$ at midday during the summer (Gimeno et al. 2008). Quercus robur L. is a common, deciduous tree species, growing under temperate climate conditions. Trees were cultivated outside in 50-L plastic containers under sufficient nutrition (Einheitserde Typ $\mathrm{T}$, Balster, Germany) and water supply, realised by periodic fertilisation with Osmocote (Bayer, Germany) and daily irrigation. All experiments were performed on current-year oak stems with no visible sign of disease, or injury. Mean plant height [m] and stem diameters $[\mathrm{mm}]$ were $1.40 \pm 0.09 \mathrm{~m}$ and $1.95 \pm 0.38 \mathrm{~mm}$ for Quercus ilex and $2.28 \pm 0.08 \mathrm{~m}$ and $2.97 \pm 0.16 \mathrm{~mm}$ for Quercus robur. During the morning hours small lateral stems of around $300 \mathrm{~mm}$ were cut from the upper sun-crown of ten different trees $(n=10)$ per species and immediately for a second time under water in order to avoid disturbances in the transpiration stream. Afterwards, samples were transferred to the laboratory for measurements. Every day fresh plant material was collected.

\subsection{Temperature treatment and chlorophyll fluorescence measurements}

For chlorophyll fluorescence measurements samples were transferred to the laboratory and were placed as a whole in a climate chamber (TS600, RS-Simulatoren, Oberhausen, Germany), which allows full control of temperature and light intensity. Samples were well-watered during the treatment to avoid any drought effect on the measurements. We found no noteworthy variation of fresh weight between the beginning and end of Chl fluorescence measurements.

The following $\mathrm{Chl} a$ fluorescence expressions, defined and calculated as described in Maxwell and Johnson (2000) and Lichtenthaler et al. (2005), were measured: $F_{v} / F_{m}$ the maximum quantum yield of PSII photochemistry, $\Delta \mathrm{F} / \mathrm{F}_{\mathrm{m}}{ }^{\prime}$ actual or effective quantum yield of PSII (in the light-adapted state), qN the nonphotochemical quenching of variable Chl fluorescence. The electron transport rate (ETR) was derived as the product of $\Delta \mathrm{F} / \mathrm{F}_{\mathrm{m}}{ }^{\prime}$ (cf. Genty et al. 1989) and quantum flux density of the incident photosynthetic active radiation (PAR, $\mu \mathrm{mol} \mathrm{m} \mathrm{m}^{-2} \mathrm{~s}^{-1}$ ), assuming an equal distribution between the two photosystems, thus only $50 \%$ of the absorbed light impinges on PSII (denoted by 0.5 ): $\mathrm{ETR}=\Delta \mathrm{F} / \mathrm{F}_{\mathrm{m}}{ }^{\prime *} \mathrm{PAR} * 0.5 *$ abs.

"Abs" describes the fraction of incident light, which is absorbed by the photosynthetic pigments of the cortex tissue. The standard version of the IMAGING-PAM (WALZ, Effeltrich, Germany) offers a special routine, which produces images of PAR-abs. For ETR calculation of the cortex tissue, we corrected PAR according to outer bark transmittance (see Table 3).

All Chl $a$ fluorescence parameters $\left(\mathrm{F}_{0}, \mathrm{~F}_{\mathrm{m}}, \mathrm{F}_{0}{ }^{\prime}, \mathrm{F}_{\mathrm{m}}{ }^{\prime}\right)$ as well as those of the fluorescence expressions

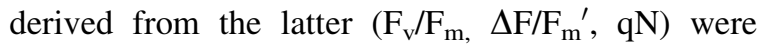
recorded with the standard-version of the IMAGINGPAM (WALZ, Effeltrich, Germany) on intact, currentyear stems.

All samples were first left to dark-adapt in the chamber for $30 \mathrm{~min}$ at $25^{\circ} \mathrm{C}$. Thereafter, the weak measurement light beam of the fluorometer was switched on to determine the minimum fluorescence $\mathrm{F}_{0}$. Subsequently, the maximum fluorescence yield $\mathrm{F}_{\mathrm{m}}$ was determined by applying a $1 \mathrm{~s}$ saturating light pulse of $3700 \mu \mathrm{mol} \mathrm{m} \mathrm{m}^{-2} \mathrm{~s}^{-1}$ via the fluorometer. Afterward, the actinic light was switched on and the sample was illuminated at a light intensity of $500 \mu \mathrm{mol}$ photons $\mathrm{m}^{-2} \mathrm{~s}^{-1}$ until steady-state photosynthesis was achieved (for $30 \mathrm{~min}$ ). Thereafter, temperatures were gradually increased. All measurements were made as follows: chamber temperature was elevated from $25^{\circ} \mathrm{C}$ to the next higher selected temperature at a rate of $3{ }^{\circ} \mathrm{C} \mathrm{min}{ }^{-1}$ and then maintained constant for at least $30 \mathrm{~min}$. Then the fluorescence parameters were monitored on the middle of the length of one intact stem (current-year-old) prior to again increase the temperature to the next higher value. The same procedure was repeated for each of seven tested temperatures in the range between 25 and $45^{\circ} \mathrm{C}\left(25^{\circ} \mathrm{C}, 30{ }^{\circ} \mathrm{C}, 35^{\circ} \mathrm{C}, 38^{\circ} \mathrm{C}, 40{ }^{\circ} \mathrm{C}, 42^{\circ} \mathrm{C}\right.$, $45^{\circ} \mathrm{C}$ ) with the same stems being used throughout the entire experiment. After the exposition of the samples to $45^{\circ} \mathrm{C}$, temperature was reduced to the initial value of $25^{\circ} \mathrm{C}$ and the samples were allowed to recover, with fluorescence parameter being recorded after 45 and $90 \mathrm{~min}$. In total, measurements were performed on 10 different stems, each derived from a different tree $(\mathrm{n}=10)$. 


\subsection{Optical properties of outer-bark}

Stem samples were taken from the upper crown of ten different trees of each species $(n=10)$ in July 2017. The bark is defined as the set of tissues external to the vascular cambium and is structurally divided into outer bark (OB) and cortex (Pfanz et al. 2002; Rosell 2016). The active stem cambia during this growth period favors the separation of the different tissue fractions (cf. Pfanz 1999; Wittmann et al. 2001; Wittmann and Pfanz 2015). OB transmittance spectra were obtained by a high-resolution fibre optic spectrometer (HR4000, Ocean Optics, Ostfildern, Germany), connected to an external integrating sphere (FOIS-1, Ocean Optics) by means of a fiber optic probe (fiber type: visible-near infrared; QP400-2VIS/BX, Ocean Optics). A tungsten-halogen light source (HL-2000, VIS-NIR, 350-1100 nm, Ocean Optics, Ostfildern, Germany), connected to the integrating sphere, served as the radiation source. The transmittance of the sample was obtained by the percentage of $\mathrm{I}: \mathrm{I}_{0}$, where I was the measured sphere output when radiation was transmitted through the sample and $\mathrm{I}_{0}$ was the measured sphere output when radiation did not pass through the sample (after removal of the sample from the course of the beam). Spectral scans were made in $1 \mathrm{~nm}$ steps over the range of 380-900 nm. The measurement configuration was set according to the manufacturer's instructions for recording transmittance spectra. For measurements of spectral reflectance of $\mathrm{OB}$, the spectrophotometer (HR4000, Ocean Optics, Ostfildern, Germany) was equipped with a reflection fiber optic probe (fiber type: visible-near infrared; R-7-VIS-NIR, Ocean Optics), directly applied on the outer bark. A reflectance standard (WS-1, Ocean Optics, Ostfildern, Germany; reflectivity $>98 \%$ from 250 to $1500 \mathrm{~nm}$ ) was used as a reference. Absorptance was calculated from the formula $\mathrm{A}=1-\mathrm{R}-\mathrm{T}$, where $\mathrm{A}, \mathrm{R}$ and $\mathrm{T}$ denote absorptance, reflectance and transmittance. With the help of the SpectraSuit operating software, the measured spectra (380-900 nm) were divided into different wavelength-bands (UVA/violet (380-420 nm), visible (380-700 nm), near infrared $(720-900 \mathrm{~nm})$, total spectrum $(380-900 \mathrm{~nm})$.

\subsection{Hairiness and tissue temperatures}

To determine possible effects of hairiness on the energy budget and thus the temperature of the stem tissues, miniaturized microsensors (FF-thermoelements with a tip diameter of $0.4 \mathrm{~mm}$; Driesen \& Kern $\mathrm{GmbH}$, Bad Bramstedt, Germany) were inserted with a micromanipulator (PreSens $\mathrm{GmbH}$, Regensburg, Germany) into the cortex tissues of hairy and nonhairy oak stems. Another thermoelement was placed $100 \mathrm{~mm}$ above the stem to measure air temperatures.

First, all stem samples were left in the climate chamber for $30 \mathrm{~min}$ at $25{ }^{\circ} \mathrm{C}(\mathrm{PAR}=0)$. At the end of this exposition time temperatures were recorded with a datalogger (Squirell SQ2040; Grant, Cambridge, UK). The same procedure was repeated for each of seven tested temperatures in the range between 25 and $45^{\circ} \mathrm{C}$ $\left(25^{\circ} \mathrm{C}, 30^{\circ} \mathrm{C}, 35^{\circ} \mathrm{C}, 38^{\circ} \mathrm{C}, 40{ }^{\circ} \mathrm{C}, 42{ }^{\circ} \mathrm{C}, 45^{\circ} \mathrm{C}\right)$ with the same stems being used throughout the entire experiment.

\subsection{Morphological analysis}

\subsubsection{Structural traits}

Micrographs of stem cross-sections were taken with a digital microscope (Keyence VHX-950F Osaka, Japan). Stem diameter and absolute and relative tissues thickness [\%] was determined with the communications software of the digital microscope. Cortex density $\left(\mathrm{D}_{\text {cortex }}\right)$, and water content $\left(\mathrm{W}_{\text {cortex }}\right)[\%]$ were determined in segments from the same branches used for histological analysis. The density $\left[\mathrm{g} \mathrm{cm}^{-3}\right]$ was calculated as tissue dry mass/tissue fresh volume (Markesteijn et al. 2011). Samples were dried at $100{ }^{\circ} \mathrm{C}$ for 4 days (Williamson and Wiemann 2010) to measure dry mass. We calculated the water content of the respective tissue as the fresh weight minus the dry weight divided by the fresh weight, to reflect the mass of water expressed as a percentage of the tissue's fresh mass.

\subsection{Chlorophyll content}

For chlorophyll extraction a $10 \mathrm{~mm}$ long segment of each sampled stem $(n=10)$ was separated into cortex and wood fraction. Cortex tissue of a known area was cut in small pieces and placed in $80 \%$ (v/v) dimethyl sulfoxide (DMSO). Pigment extraction required 
approximately $2 \mathrm{~h}$ at $65^{\circ} \mathrm{C}$ in the dark. To avoid acidification and a concomitant phaeophytinisation of the chlorophylls, $20 \mathrm{mg} \mathrm{Mg}_{2}(\mathrm{OH})_{2} \mathrm{CO}_{3}$ was added. Finally, extract absorbance was measured with a spectrophotometer (UV 160, Shimadzu, Japan) and pigment contents calculated according to standard equations (Wellburn 1994).

\subsection{Data analysis}

All statistical data analyses were performed with SigmaPlot 12.5 (SPSS inc., Chicago, IL, USA) and IBM SPSS Statistics version 25 (IBM corp., New York, USA). ANOVA using general linear models (GLM) procedure was employed for testing species, tissue and species*tissue effects on structural traits of stems. Prior to analysis, data were checked for normality using a Shapiro-Wilk test and for homogeneity using Levene's test at $\mathrm{P}<0.05$. Data were transformed, if necessary, to prevent violation of ANOVA theory. Simple linear regression analysis was carried out to test for pairwise associations between effective quantum efficiency (yield) of PSII and optical and structural stem traits. In addition, statistical significance of differences between data sets was examined by Student's $t$-tests.

\section{Results}

\subsection{Optical properties of hairy versus non-hairy stems}

Microscopic examination of current-year Quercus ilex stems showed an outer bark (OB) with numerous, nonglandular, white trichomes (Fig. 1c, d). In Quercus robur no hairy OB was apparent (Fig. 1a, b).

Hairiness clearly affected stem optical properties (Fig. 2). OB of Quercus ilex showed poor reflection of light in the 420-450 $\mathrm{nm}$ band, but quite an enhanced reflectance of short wavelengths of UV/violet $(380-420 \mathrm{~nm})$. At wavelengths $>500 \mathrm{~nm}$ OB reflectance was substantially greater in the hairy compared with non-hairy oak species (Fig. 2a, Table 3). Accordingly, reflectance of $\mathrm{OB}$ averaged across the visible $(380-720 \mathrm{~nm})$ and infrared spectrum $(720-900 \mathrm{~nm})$ was significantly $(\mathrm{P}<0.0001)$ higher in holm oak as compared to non-hairy common oak stems (Fig. 2a, Table 3).
Spectral absorptance of OB in the visible part of the spectrum $(380-720 \mathrm{~nm})$ was also significantly $(\mathrm{P}<0.0001)$ higher in the hairy compared with nonhairy oak species (Fig. 2b, Table 3), while no significant $(\mathrm{P}=0.193)$ differences between both species were found in the near infrared part of the spectrum. Both, OB reflectance (R) and absorptance (A), had an impact on OB transmittance ( $\mathrm{T}=1-\mathrm{R}-\mathrm{A})$. The efficient absorptance of hairy $\mathrm{OB}$ in the visible part of the spectrum resulted in a significantly $(\mathrm{P}<0.0001)$ lower PAR-transmittance of OB $(-15 \%)$ (Fig. 2c, Table 3). The reflectance of hairy OB averaged across the NIR-spectrum $(720-900 \mathrm{~nm})$ was three times higher than that of non-hairy stems, while the transmittance across the NIR-spectrum was $6 \%$ lower than that of non-hairy ones (Table 3). Altogether, OB transmittance was over all wavelength bands significantly lower in Quercus ilex as compared to Quercus robur stems (Fig. 2c, Table 3).

\subsection{Hairiness and tissue temperatures}

Comparison of air and tissue temperatures showed, that no significant differences between air temperature $\left(\mathrm{T}_{\text {air }}\right)$ and cortex temperature ( $\left.\mathrm{T}_{\text {cortex }}\right)$ of non-hairy common oak stems were apparent, but $\mathrm{T}_{\text {cortex }}$ of hairy Quercus ilex stems were significantly lower $(\mathrm{P}<0.05)$ than those of non-hairy Quercus robur stems (Fig. 3). The difference in mean $\mathrm{T}_{\text {cortex }}$ reached at $45{ }^{\circ} \mathrm{C}$ a maximum of $3.6^{\circ} \mathrm{C}$ (Fig. 3a).

$\mathrm{T}_{\text {cortex }}$ of hairy and non-hairy oak stems were differently effected by an increase in PAR intensity (Fig. 3b). While only marginal differences between $\mathrm{T}_{\text {air }}$ and $\mathrm{T}_{\text {cortex }}$ of common oak stems with increasing PAR-intensity was found, $\mathrm{T}_{\text {cortex }}$ of holm oak was significantly lower $(\mathrm{P}<0.05)$ as compared to $\mathrm{T}_{\text {cortex }}$ of common oak at high PAR intensities $(\geq 1000 \mu \mathrm{mol}$ photons $\mathrm{m}^{-2} \mathrm{~s}^{-1}$ ). The difference between mean $\mathrm{T}_{\text {air }}$ and $\mathrm{T}_{\text {cortex }}$ of holm oak reached at $2500 \mu \mathrm{mol}$ photons $\mathrm{m}^{-2} \mathrm{~s}^{-1}$ a maximum of $2.7^{\circ} \mathrm{C}$ (Fig. 3b). At PAR intensities $\leq 750 \mu \mathrm{mol}$ photons $\mathrm{m}^{-2} \mathrm{~s}^{-1}$ no significant differences between $\mathrm{T}_{\text {cortex }}$ of both oak species and $\mathrm{T}_{\text {air }}$ were apparent (Fig. 3b).

\subsection{Stem structural traits}

Absolute and relative thickness of $\mathrm{OB}$ was significantly higher in holm oak as compared to common oak stems (Table 1$)$. Cortex density $\left(\mathrm{D}_{\text {cortex }}\right)$ and water 

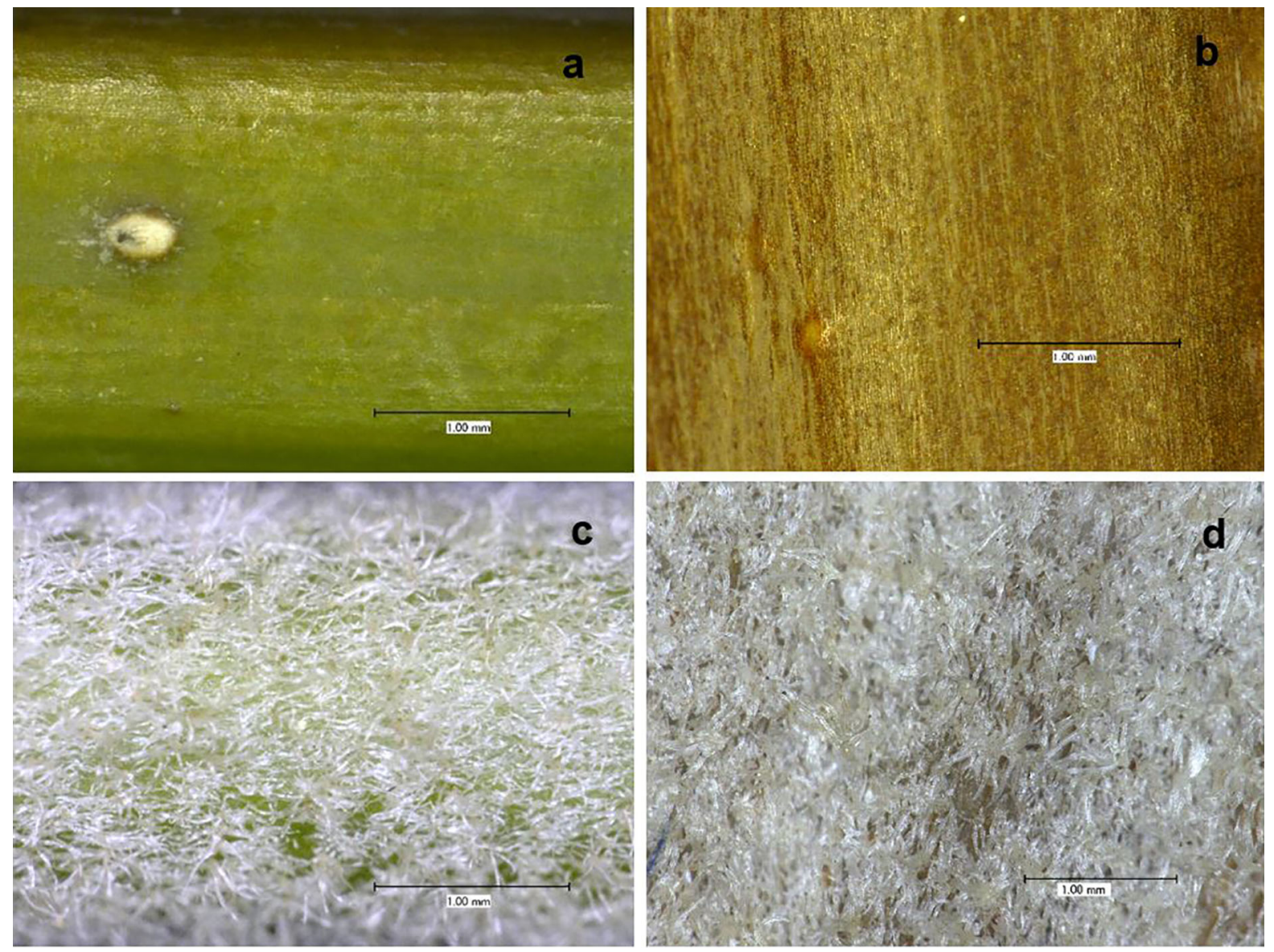

Fig. 1 Digital microscope micrographs of outer bark surfaces. a, b Surface of non-hairy outer bark of Quercus robur showing no trichomes. c, $\mathbf{d}$ Surface of hairy outer bark of Quercus ilex

showing a dense layer of white trichomes. a, c Surface of intact stems; b, d surface of isolated outer bark

content $\left(\mathrm{W}_{\text {cortex }}\right)$ was significantly lower in Quercus ilex $(\mathrm{P}<0.05)$ as compared to Quercus robur (Table 1).

A significant $(\mathrm{P}<0.05)$ effect of species and tissue, except for tissue density, on structural stem traits was found (Table 1). An additive species*tissue effect was found for tissue thickness [mm] (Table 1).

\subsection{Chlorophyll content}

The chlorophyll content of the cortex tissue was not significantly $(\mathrm{P}>0.05)$ different in Quercus ilex as compared to Quercus robur (Table 2). Accordingly, PAR-absorptivity (Abs) showed no significant difference between both species (Table 2).

\subsection{Stem photochemistry}

In both oak species, values of $\mathrm{F}_{\mathrm{v}} / \mathrm{F}_{\mathrm{m}}$ were relatively constant at temperatures below $40{ }^{\circ} \mathrm{C}$ (Fig. $4 \mathrm{a}, \mathrm{b}$ ). At temperatures higher than $40{ }^{\circ} \mathrm{C}, \mathrm{F}_{\mathrm{v}} / \mathrm{F}_{\mathrm{m}}$ of current-year stems decreased much more abruptly for Quercus robur compared with Quercus ilex (Fig. 4a, b).

At $45{ }^{\circ} \mathrm{C}$, the $\mathrm{F}_{\mathrm{v}} / \mathrm{F}_{\mathrm{m}}$ ratio of holm oak stems was less than $15 \%$ reduced as compared with those at $25{ }^{\circ} \mathrm{C}$. The $\mathrm{F}_{\mathrm{v}} / \mathrm{F}_{\mathrm{m}}$ ratio of Quercus robur was $37 \%$ reduced in stems treated at $45^{\circ} \mathrm{C}$ as compared with those at $25{ }^{\circ} \mathrm{C}$ (Fig. 4b). The $\mathrm{F}_{\mathrm{v}} / \mathrm{F}_{\mathrm{m}}$ ratio exhibited a more sensitive reaction of maximum quantum yield of PSII of common oak stems under heat stress. At temperatures above $35{ }^{\circ} \mathrm{C}$, the $\mathrm{F}_{\mathrm{v}} / \mathrm{F}_{\mathrm{m}}$ ratio of common oak stems was significantly lower than that of hairy holm oak stems (Fig. 4). 

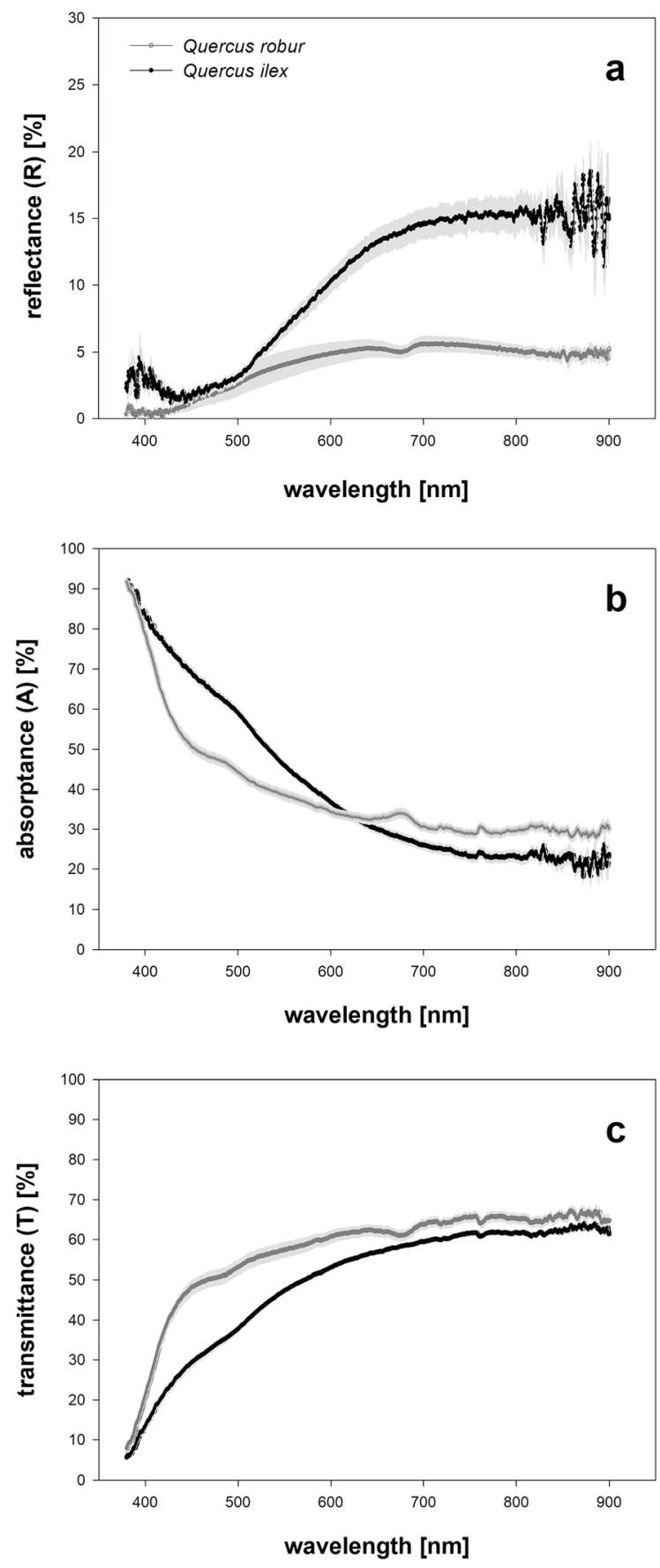

Fig. 2 Spectral properties of outer bark of hairy (Quercus ilex) and non-hairy (Quercus robur) stems. Reflectance-(a), absorptance-(b) and transmittance-spectra (c) as measured on outer bark of current-year stems. Data are means \pm SE (grey bars); $\mathrm{n}=10$. The insert in $\mathbf{c}$ shows the changes in outer-bark transmittance in the infrared part $(700-900 \mathrm{~nm})$ of the spectrum
The heat-induced reduction of the $\mathrm{F}_{\mathrm{v}} / \mathrm{F}_{\mathrm{m}}$ ratio originated from both a decrease of $F_{m}$ and an increase of $F_{0}$ (data not shown). The critical temperature at which basal fluorescence $\left(\mathrm{F}_{0}\right)$ starts to increase was $42{ }^{\circ} \mathrm{C}$ in Quercus ilex stems and $35^{\circ} \mathrm{C}$ in those of Quercus robur (data not shown). However, if the $\mathrm{F}_{\mathrm{v}} /$ $\mathrm{F}_{\mathrm{m}}$ values of Quercus ilex are replotted as a function of cortex tissue temperature $\left(\mathrm{T}_{\text {cortex }}\right)$ rather than air temperature (grey symbols in Fig. 4), then data of both species lie nearly on a single line (Fig. 4).

Furthermore, effective quantum yield of PSII $(\Delta \mathrm{F} /$ $\mathrm{F}_{\mathrm{m}}{ }^{\prime}$ ) and non-photochemical quenching of chorophyll fluorescence $(\mathrm{qN})$ were more sensitive to high temperatures $\left(>40{ }^{\circ} \mathrm{C}\right)$ in Quercus robur as compared to Quercus ilex stems (Fig. 5). High-temperature dependent reduction of $\Delta \mathrm{F} / \mathrm{F}_{\mathrm{m}}{ }^{\prime}$ was associated with an increase of thermal dissipation of excess excitation energy, as reflected by an increase of qN (Fig. 5b). At moderate temperatures, photon-based ETR of hairy holm oak stems was significantly lower $(\mathrm{P}<0.001)$ compared with non-hairy stems of Quercus ilex. However, ETR of PSII exhibited a higher dynamic range under heat stress in non-hairy common oak stems and a large significant decline in ETR at temperatures $>38^{\circ} \mathrm{C}$, while in hairy oak stems ETR changed comparably little under heat stress (Fig. 5c). At $45{ }^{\circ} \mathrm{C}$ ETR of Quercus ilex stems was reduced to only $73 \%$ of the value measured under the initial temperature of $25^{\circ} \mathrm{C}$, while in non-hairy stems of Quercus robur ETR was reduced to even $43 \%$ of the initial temperature value (Fig. 5c). If the $\Delta \mathrm{F} / \mathrm{F}_{\mathrm{m}}{ }^{\prime}$ data of Quercus ilex are replotted as a function of $\mathrm{T}_{\text {cortex }}$ (grey symbols in Fig. 5a) rather than air temperature, then differences between species diminish under high temperatures (Fig. 5a).

Simple linear regression analysis revealed no significant effect of stem structural traits on corticular photochemistry ( $\mathrm{PS}_{\text {cort }}$ ), while all measured optical traits of outer bark were significantly $(\mathrm{P}<0.01)$ correlated with $\mathrm{PS}_{\text {cort }}$; $\mathrm{OB}$ reflectance explained up to $91 \%$ of the variation in PSII quantum yield (Table 4).

Recovery from heat stress also showed considerable variation between both species (Fig. 6). Hairy stems of Quercus ilex showed almost complete poststress recovery of photosynthetic PSII efficiency. After $90 \mathrm{~min}$ at $25^{\circ} \mathrm{C}$ maximum and effective quantum efficiency of PSII of hairy stems progressively recovered to about 91 and $94 \%$ of its initial value 
Fig. 3 Effect of air temperature on inner bark (= cortex) temperatures as measured on hairy (Quercus ilex) and non-hairy (Quercus robur), currentyear stems. Data are means \pm SE (black bars); $\mathrm{n}=6$. Asterisks indicate significant differences between species as examined by Student's $t$ tests $(* \mathrm{P}<0.05$, $* * \mathrm{P}<0.01, * * * \mathrm{P}<0.001)$. A linear regression line is drawn for air temperature and each species of the current plot. Regression statistics (coefficient of determination $r^{2} ; P$ values) are for Quercus ilex: $r^{2}=0.998, P<0.0001 ;$ Quercus robur: $r^{2}=0.998$, $P<0.0001$

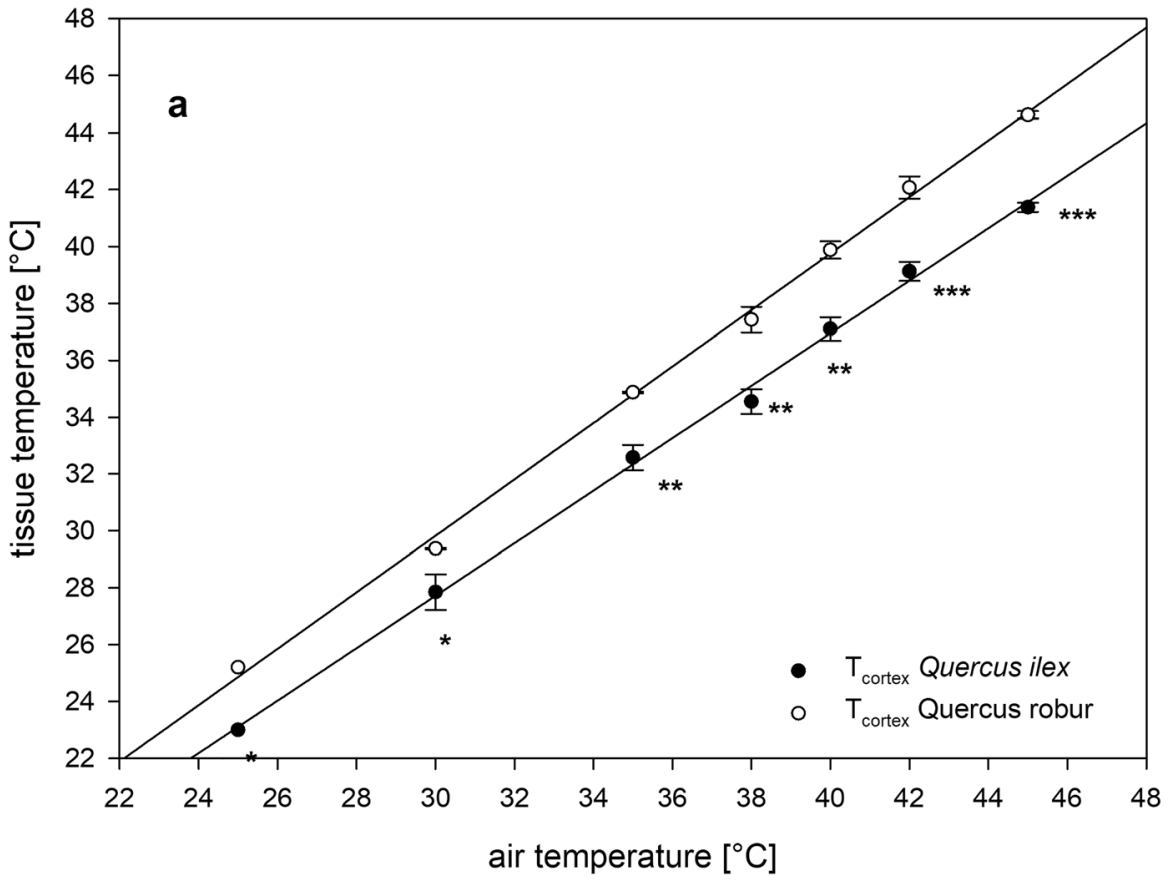

Table 1 Stem structural traits. Data are the mean \pm SD from ten replicates $(n=10)$

\begin{tabular}{|c|c|c|c|c|c|c|c|}
\hline Tissue & Trait & Querus ilex & Quercus robur & Effect & $d f$ & $F$ & $P$ value \\
\hline Outer bark & Thickness [mm] & $0.08 \pm 0.01$ & $0.06 \pm 0.01$ & Species & 1 & 24.5 & 0.000 \\
\hline \multirow[t]{2}{*}{ Cortex } & \multirow[t]{2}{*}{ Thickness [mm] } & \multirow[t]{2}{*}{$0.36 \pm 0.06$} & \multirow[t]{2}{*}{$0.53 \pm 0.06$} & Tissue & 1 & 608 & 0.000 \\
\hline & & & & Species*tissue & 1 & 37.3 & 0.000 \\
\hline Outer bark & Relative thickness $[\%]^{\mathrm{a}}$ & $8.63 \pm 1.87$ & $4.32 \pm 0.75$ & Species & 1 & 6.06 & 0.020 \\
\hline \multirow[t]{2}{*}{ Cortex } & \multirow[t]{2}{*}{ Relative thickness $[\%]^{\mathrm{a}}$} & \multirow[t]{2}{*}{$37.7 \pm 4.48$} & \multirow[t]{2}{*}{$35.9 \pm 5.12$} & Tissue & 1 & 584 & 0.000 \\
\hline & & & & Species*tissue & 1 & 0.95 & 0.337 \\
\hline \multirow[t]{2}{*}{ Cortex } & Density $\left(\mathrm{D}_{\text {cortex }}\right)\left[\mathrm{g} \mathrm{cm}^{-3}\right]$ & $0.40 \pm 0.09$ & $0.50 \pm 0.10$ & Species & 1 & 4.22 & 0.024 \\
\hline & Water content $\left(\mathrm{W}_{\text {cortex }}\right)[\%]$ & $59.4 \pm 3.14$ & $63.7 \pm 5.88^{*}$ & Species & 1 & 1.41 & 0.047 \\
\hline
\end{tabular}

Results of ANOVA for the effects of species, tissue and their interaction on the parameters are shown. P-values for significant effects are shown in bold

${ }^{\text {a }}$ Relative to stem diameter

(Fig. 6a, b). On the contrary, in non-hairy stems sustained heat-induced photoinhibition was apparent even after 90 min recovery (Fig. 6). Recovery of photosynthetic PSII efficiency was much slower in common oak as compared to holm oak stems and maximum and effective quantum efficiency remained reduced by 50 and $30 \%$ even after $90 \mathrm{~min}$ at $25^{\circ} \mathrm{C}$. The pronounced $\mathrm{qN}$ that appeared at the end of the heat stress period markedly relaxed in both species during recovery and was about its initial level after $90 \mathrm{~min}$ at $25^{\circ} \mathrm{C}$ (Fig. 6c).

\section{Discussion}

4.1 Optical and structural properties of stems

Leaf hairs modify the internal radiation environment of a leaf (Karabourniotis and Bornman 1999). Our 
Table 2 Chlorophyll content and PAR-absorptivity of current-year-old stems of Quercus ilex and Quercus robur tees

\begin{tabular}{llrr}
\hline Tissue & Parameter & Querus ilex & Quercus robur \\
\hline Cortex & $\operatorname{chl} a\left[\mathrm{mg} / \mathrm{m}^{2}\right]$ & $127 \pm 27.3$ & $116 \pm 36.3^{\mathrm{ns}}$ \\
& $\operatorname{chl} b\left[\mathrm{mg} / \mathrm{m}^{2}\right]$ & $110 \pm 21.8$ & $114 \pm 22.3^{\mathrm{ns}}$ \\
& $\operatorname{chl}(a+b)\left[\mathrm{mg} / \mathrm{m}^{2}\right]$ & $238 \pm 49.2$ & $230 \pm 52.0^{\mathrm{ns}}$ \\
& $\operatorname{Abs}^{\mathrm{a}}$ & $0.75 \pm 0.03$ & $0.77 \pm 0.05^{\mathrm{ns}}$ \\
\hline
\end{tabular}

Data are the mean \pm SD from ten replicates $(n=10)$

${ }^{a}$ PPFD-absorptivity as measured by means of a standard Imaging-PAM fluorometer (Walz)

${ }^{n s}$ Differences are not significant. $P>0.05$ as examined by Student's $t$-tests

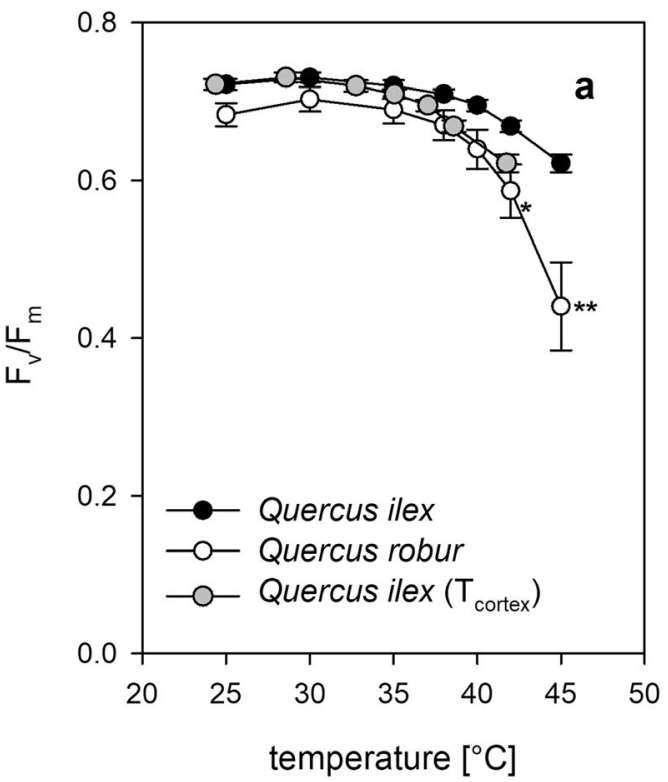

Fig. 4 Effect of air temperature on maximum quantum yield of PSII $\left(F_{v} / F_{m}\right)(\mathbf{a})$ of current-year-stems; with the data in (b) being expressed as a percentage of the corresponding initial values determined at $25{ }^{\circ} \mathrm{C}$. Data are means $\pm \mathrm{SE}(\mathrm{n}=10)$. Asterisks indicate significant differences between pubescent (Quercus

results show that this holds true also for stem hairs. The hairiness of oak stems had marked effects on stem optical properties and thus, the light environment of the underlying cortex tissue (Fig. 2).

The hairy $\mathrm{OB}$ of holm oak stems showed a significantly higher absorption in the visible part of the spectrum as compared to non-hairy oak stems, which reduced the amount of photosynthetically active photons falling on the underlying cortex tissue on average for $15 \%$. In leaf hairs, absorption of these wavelengths is due to phenolic ingredients or other PAR-absorbing compounds (Skaltsa et al. 1994). Such

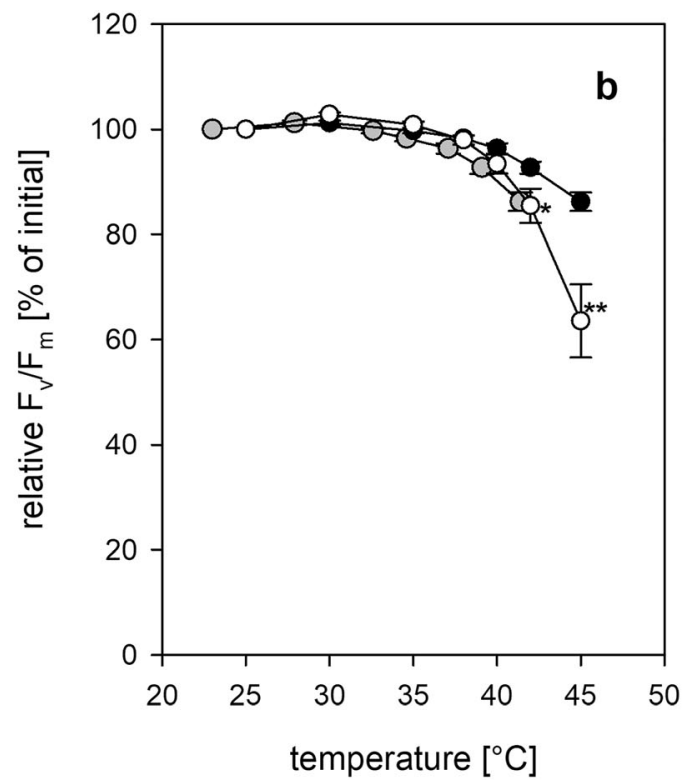

ilex) and non-pubescent stems (Qercus robur) as examined by Student's $t$-tests $(* \mathrm{P}<0.05, * * \mathrm{P}<0.01$, ***P $<0.001)$. Grey symbols give data of Quercus ilex replotted as a function of cortex temperature $\left(\mathrm{T}_{\text {cortex }}\right)$ rather than air temperature

absorbing compounds (flavonoids, anthocyanins, phenolics) exist in leaf hairs of the Mediterranean species Quercus ilex (Skaltsa et al. 1994), thus, similar PARabsorbing ingredients can also be expected for hairy OB of Quercus ilex stems.

Furthermore, hairy holm oak stems were significantly more effective in reflecting longer wavelength (500-900 nm) than non-hairy common oak stems (Fig. 2). Leaf trichomes play an important role in the leaf energy budget, as reflectors of visible and infrared radiation, resulting in a lower leaf heat load (Ehleringer and Mooney 1978). Our results confirm this 

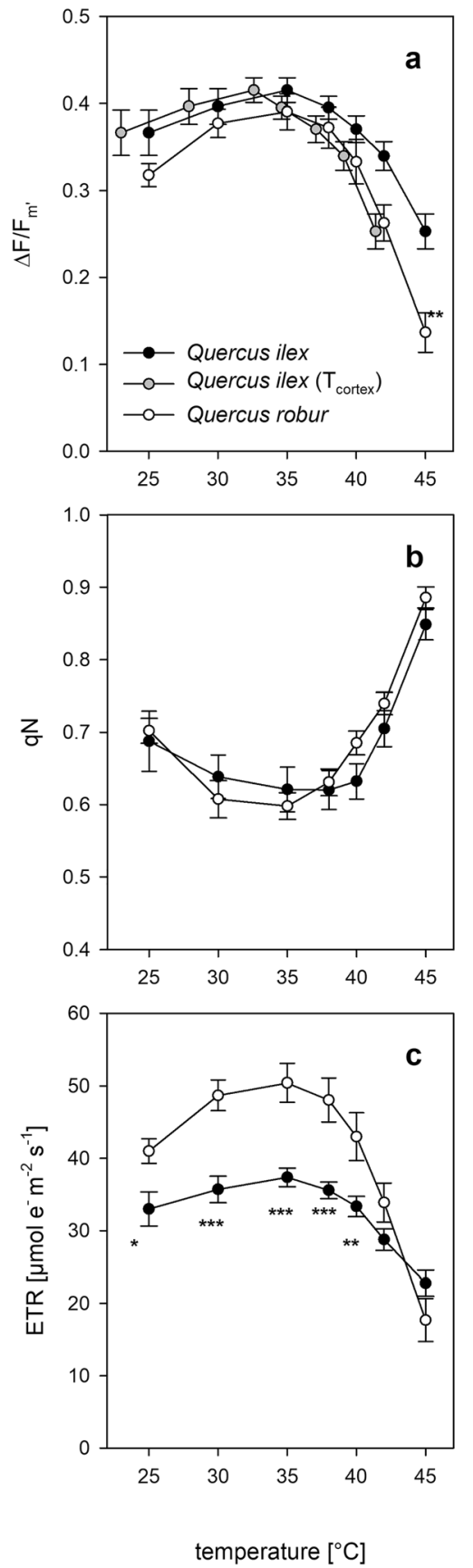

protective function against high temperatures also for stem hairs (Fig. 3). Oak stems with hairy OB were more effective in reflecting longer wavelengths $(>490 \mathrm{~nm})$ and absorbing lower wavelengths $(<650 \mathrm{~nm})$. Consequently, spectral transmittance of hairy OB was $15 \%$ lower in the PAR and $6 \%$ lower in the NIR part of the spectrum, compared with non-hairy
4Fig. 5 Effect of air temperature on effective quantum yield of PSII (a), non-photochemical quenching coefficient qN (b) and electron transport rate of PSII (ETR) $\left[\mu \mathrm{mol} \mathrm{e}^{-} \mathrm{m}^{-2} \mathrm{~s}^{-1}\right]$ (c). Data are means \pm SE $(n=10)$. For calculaton of ETR the PSII yield data shown in panel (a) and the PAR corrected according to OB transmittance (Table 3) were used. Asterisks indicate significant differences between hairy (Quercus ilex) and nonhairy stems (Qercus robur) as examined by Student's $t$-tests $(* \mathrm{P}<0.05, * * \mathrm{P}<0.01$, *** $\mathrm{P}<0.001)$. Grey symbols in (a) give data of Quercus ilex replotted as a function of cortex temperature $\left(\mathrm{T}_{\text {cortex }}\right)$ rather than air temperature

OB of common oak (Fig. 2, Table 3). Thus, the trichomes covering photosynthetic stems of Quercus ilex protect the underlying cortex tissues against radiation damage and overheating simply by reducing the amount of photons transmitted through the outer bark and thus, impinging on the cortex tissues. This was also shown by the significantly lower $(\mathrm{P}<0.05)$ $\mathrm{T}_{\text {cortex }}$ of hairy Quercus ilex stems as compared to nonhairy Quercus robur stems. The spectral properties of the stem hairs reduced the heat load of the stem resulting in an inner bark temperature lower than that of the air (Fig. 3).

Nevertheless, besides hair covering, stems of both oak species showed also some structural differences. Absolute and relative thickness of $\mathrm{OB}$ was significantly higher in Querus ilex as compared to Quercus robur (Table 1). $\mathrm{D}_{\text {cortex }}$ and $\mathrm{W}_{\text {cortex }}$ of Quercus ilex was significantly lower $(\mathrm{P}<0.05)$ as compared to Quercus robur (Table 2).

Bark (= all tissues outside the vascular cambium; OB + cortex) has excellent heat insulation properties, which are mostly determined by tissue thickness (Vines 1968) and to a lesser extent by tissue density and moisture content (Brando et al. 2012; Poorter et al. 2014). Bark heat insulation increases with the square of bark thickness (Poorter et al. 2014). Despite this, Brando et al. (2012) found that increased water content of bark was associated with an increased heat transfer rate, probably because of the high thermal conductivity of water. Thus, besides trichomes, these structural traits can also partly have affected thermal balance of stems. Variation in cortex structure among species can also be the result of different strategies of water use and conservation, besides reflecting contrasting metabolic demands (Rosell 2016; LoramLourenco et al. 2020). The variation in structural bark morphology found in the studied Quercus taxa might 
Table 3 Transmittance (T), absorptance (A) and reflectance (R) [\%] of the outer bark (periderm) of current-year stems of common oak $(\mathrm{Qr}=$ Quercus robur $)$ and holm oak $(\mathrm{Qi}=$ Quercus ilex $)$ trees as measured within different wavelength bands of the spectrum

\begin{tabular}{|c|c|c|c|c|c|c|}
\hline \multirow{2}{*}{$\begin{array}{l}\text { Parameter } \\
\text { Species }\end{array}$} & \multicolumn{2}{|c|}{ Transmittance $(\mathrm{T})[\%]$} & \multicolumn{2}{|c|}{ Absorptance (A) [\%] } & \multicolumn{2}{|c|}{ Reflectance (R) [\%] } \\
\hline & Qi & Qr & Qi & Qr & Qi & Qr \\
\hline $\begin{array}{l}\text { UV/violet } \\
(380-420 \mathrm{~nm})\end{array}$ & $14.32 \pm 1.27$ & $25.24 \pm 1.28 * * *$ & $83.92 \pm 1.30$ & $74.76 \pm 1.28 * * *$ & $1.75 \pm 0.64$ & $0.00 \pm 0.00^{*}$ \\
\hline $\begin{array}{l}\text { PAR } \\
(380-720 \mathrm{~nm})\end{array}$ & $47.39 \pm 1.01$ & $61.94 \pm 1.87 * * *$ & $43.10 \pm 1.66$ & $34.30 \pm 1.55^{* *}$ & $9.52 \pm 1.07$ & $3.77 \pm 0.67 * * *$ \\
\hline $\begin{array}{l}\text { NIR } \\
(720-900 \mathrm{~nm})\end{array}$ & $60.59 \pm 0.62$ & $66.72 \pm 1.51^{* *}$ & $26.77 \pm 1.54$ & $20.16 \pm 1.60$ & $12.64 \pm 1.53$ & $3.62 \pm 0.33^{* * *}$ \\
\hline $\begin{array}{l}\text { Total spectrum } \\
(380-900 \mathrm{~nm})\end{array}$ & $50.48 \pm 1.21$ & $62.58 \pm 0.59 * * *$ & $41.01 \pm 2.49$ & $30.75 \pm 0.77 * *$ & $11.83 \pm 1.43$ & 3. $67 \pm 0.53 * * *$ \\
\hline
\end{tabular}

Data are the mean \pm SE from ten replicates $(n=10)$. Asterisks indicate significant differences between species as examined by Student's t-tests $(* \mathrm{P}<0.05 ; * * \mathrm{P}<0.01 ; * * * \mathrm{P}<0.001)$

Table 4 Correlation analysis between effective quantum yield of PSII $\left(\Delta \mathrm{F} / \mathrm{F}_{\mathrm{m}}{ }^{\prime}\right)$ and optical and structural traits of current-year oak stems

\begin{tabular}{|c|c|c|c|c|}
\hline \multirow[t]{2}{*}{ Trait } & \multicolumn{2}{|c|}{$\Delta \mathrm{F} / \mathrm{F}_{\mathrm{m}}{ }^{25}$} & \multicolumn{2}{|c|}{$\Delta \mathrm{F} / \mathrm{F}_{\mathrm{m}}{ }^{\prime 45}$} \\
\hline & $r$ & $P$ & $r$ & $P$ \\
\hline OB reflectance $(380-900 \mathrm{~nm})[\%]$ & 0.844 & $0.000 * * *$ & 0.914 & $0.000 * * *$ \\
\hline OB absorptance $(380-900 \mathrm{~nm})[\%]$ & 0.696 & $0.002 * *$ & 0.738 & $0.001 * *$ \\
\hline OB transmittance $(380-900 \mathrm{~nm})[\%]$ & 0.639 & $0.006 * *$ & 0.845 & $0.000 * * *$ \\
\hline OB thickness (OBT) [mm] & 0.243 & 0.348 & 0.403 & 0.108 \\
\hline Water content $\left(\mathrm{W}_{\text {cortex }}\right)[\%]$ & 0.478 & 0.052 & 0.488 & 0.051 \\
\hline Density $\left(\mathrm{D}_{\text {cortex }}\right)\left[\mathrm{g} \mathrm{cm}^{-3}\right]$ & 0.461 & 0.084 & 0.473 & 0.075 \\
\hline
\end{tabular}

P-values for significant effects are shown in bold. $N=20$

$r$ Pearson correlation coefficient; Italics indicate the highest $r$

*Significant at $\mathrm{P}<0.05$; **Significant at $\mathrm{P}<0.01$; ***Significant at $\mathrm{P}<0.001$

${ }^{25}$ Measurements were performed at $25{ }^{\circ} \mathrm{C}$

${ }^{45}$ Measurements were performed at $45^{\circ} \mathrm{C}$

also reflect that both species vary in their natural distribution, having adapted to a Mediterranean and temperate climate, leading to diverse morphologies as well as to differences in life strategies and nutrient/ biomass allocations (Bonfil et al. 2004).

\subsection{Temperature effects on stem photochemistry and its interaction with stem structural traits}

Fluorescence methods used to evaluate thermal damage to photosynthetic leaf tissue traditionally measure the maximum quantum yield $\left(\mathrm{F}_{\mathrm{v}} / \mathrm{F}_{\mathrm{m}}\right)$ of PSII (Curtis et al. 2014). The moderate temperatures $\left(30-35^{\circ} \mathrm{C}\right)$ imposed to the oak stems during the temperature experiment never induced a severe decay of the photosynthetic apparatus in the cortex tissue, as shown by the almost complete stability of the maximum quantum yield of PSII (Fig. 4). Nevertheless, the temperature of $38{ }^{\circ} \mathrm{C}$ was already at the threshold of damaging levels, as shown by the small decrease of $\mathrm{F}_{\mathrm{v}} /$ $\mathrm{F}_{\mathrm{m}}$ between 35 and $38{ }^{\circ} \mathrm{C}$ (Fig. 4a). Similar observations have been reported for leaves of different oak species (Daas et al. 2008; Ghouil et al. 2003). Above $40{ }^{\circ} \mathrm{C}$, maximum quantum yield of PS II $\left(\mathrm{F}_{\mathrm{v}} / \mathrm{F}_{\mathrm{m}}\right)$ of 

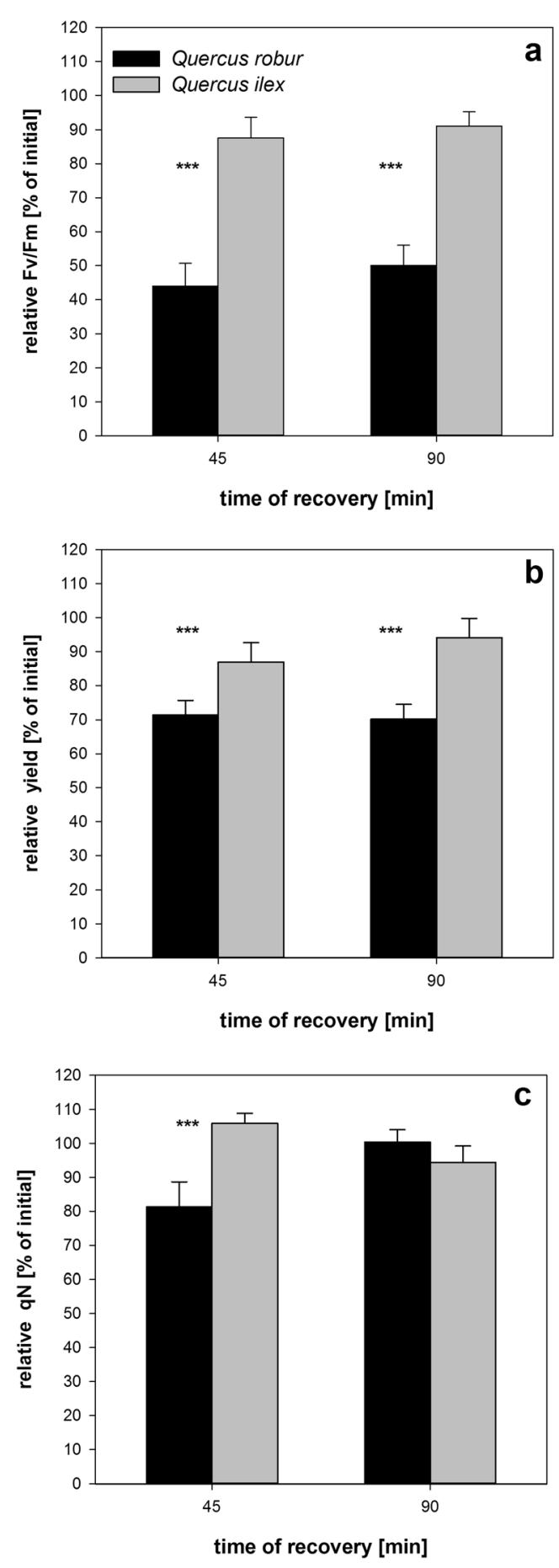

current-year oak stems decreased. Thereby, temperature response of $\mathrm{F}_{\mathrm{v}} / \mathrm{F}_{\mathrm{m}}$ exhibited a higher dynamic range and a large significant decline in non-hairy as compared to hairy oak stems at temperature $\geq 38{ }^{\circ} \mathrm{C}$ (Fig. 4). The decline in $\mathrm{F}_{\mathrm{v}} / \mathrm{F}_{\mathrm{m}}$ at high temperatures
4Fig. 6 Photosynthetic fluorescence parameter of common oak (white bars) and holm oak (grey bars) stems during the recovery period following the heat stress treatment. After the last temperature step of the heat stress experiment $\left(45^{\circ} \mathrm{C}\right)$, temperature was reduced to $25{ }^{\circ} \mathrm{C}$ and recovery from heatinduced changes in chlorophyll fluorescence was determined after 45 and $90 \mathrm{~min}$. All data are expressed as a percentage of the corresponding initial values determined at $25^{\circ} \mathrm{C}$ at the beginning of the heat stress treatment. Data are means $\pm \mathrm{SE}$ $(\mathrm{n}=10)$. Asterisks indicate significant differences between species as examined by Student's $t$-tests $(* * * \mathrm{P}<0.001)$

was associated with a decrease in $\mathrm{F}_{\mathrm{m}}$ and an increase in $\mathrm{F}_{0}$ (data not shown); in leaves this was attributed to conformational changes in PSII associated with thermal energy dissipation (Demming-Adams et al. 1998; Dreyer et al. 2001).

Optimal temperatures for leaf net photosynthesis are around $30{ }^{\circ} \mathrm{C}$ or slightly higher, whereas the optimum temperatures for photosynthetic electron transport are typically $5-15^{\circ} \mathrm{C}$ higher (Niinemets et al. 1999; Medlyn et al. 2002). In our study, the rate of ETR of current-year stems peaked at a temperature of around $35^{\circ} \mathrm{C}$ (Fig. 5c). At optimal temperature $\left(\mathrm{T}_{\mathrm{opt}}\right)$, photosynthetic ETR of hairy holm oak stems was on average $26 \%$ lower than that of non-hairy common oak stems (Fig. 5c). OB transmittance in the visible part of the spectrum was $15 \%$ lower in hairy as compared to non-hairy oak stems (Fig. 2c, Table 3). If we assume the same PSII quantum yield for both species and calculate the ETR for both species with a PAR value corrected for the specific OB transmittance, we get a difference in ETR values of around $24 \%$. Thus, differences in photosynthetic ETR are largely attributable to OB optical properties. Other structural bark traits might also contributed to the observed difference in ETR at $\mathrm{T}_{\text {opt }}$. Cortex thickness of common oak stems was significantly higher as compared to holm oak stems (Table 1), which could have led to a comparably higher area based ETR. Due to the phloem, the cortex is also involved in the transport of photosynthates and other substances, which reinforces the importance of this structure in the maintenance of central physiological processes (Rosell 2016, Loram-Lourenco et al. 2020). We used simple linear regression analysis to test for associations between PSII quantum yield and optical and structural bark traits. OB optical properties significantly affected corticular photochemistry ( $\left.\mathrm{PS}_{\text {cort }}\right)$ 
(Table 4), but we found no significant effect of structural stem traits on PSII quantum yield (Table 4). Thus, stem optical traits, which are clearly modified by hairiness (Fig. 2), were the only probable predictors of $\mathrm{PS}_{\text {cort }}$ in this study.

Photosynthetic ETR at suboptimal temperatures of $45{ }^{\circ} \mathrm{C}$ was reduced in Quercus robur to $43 \%$ of the initial temperature value, while ETR of Quercus ilex stems was reduced to only $73 \%$ of the value measured under the initial temperature of $25{ }^{\circ} \mathrm{C}$ (Fig. 5c). ETR largely depends on thylakoid membrane integrity, which in leaves is disturbed at temperatures above $38^{\circ} \mathrm{C}$ (Havaux et al. 1996). Accordingly, heatinduced disturbance of thylakoid membrane integrity might have been higher in non-hairy as compared to hairy oak stems. Hairs have shown to affect the photosynthetic rate and the degree of photoinhibition. These effects were attributed most notably to a reduction in absorbed PAR (Ehleringer and Mooney 1978; Ehleringer 1984) and altered leaf temperatures (Ehleringer and Bjorkman 1978).

In this study, the increased light reflectance from hairy OB of stems together with a high PAR-absorptance might have reduced inhibition of $\mathrm{PS}_{\text {cort }}$ under heat-stress in two ways: either by reducing excess light absorption and by reducing thermal load (= overheating avoidance function) (Fig. 3). The relationship between air and tissue temperatures shown in Fig. 3 underlines this assumption; $\mathrm{T}_{\text {cortex }}$ of hairy Quercus ilex stems were significantly lower $(\mathrm{P}<0.05)$ than those of non-hairy Quercus robur stems (Fig. 3). Accordingly, differences in temperature response of $\mathrm{PS}_{\text {cort }}$ between both species was partly removable by plotting the data on a tissue temperature instead of an air temperature basis (Figs. 4 and 5). This finding indirectly links differences in PSII quantum yield to differences in outer bark optical properties (Figs. 4 and5). Furthermore, $\mathrm{PS}_{\text {cort }}$ of non-hairy common oak stems was less resilient against high-temperature stress than that of hairy ones (Figs. 4 and 5). Furthermore, our experiment showed that holm oak seedlings were able to maintain corticular photochemistry under high temperatures, a stress-tolerance strategy that is in agreement with other studies of this species in leaves (Martínez-Ferri et al. 2004, Valladares et al. 2008).

Recovery from heat stress showed also considerable variation between both species (Fig. 6). Hairy stems of Quercus ilex showed almost complete recovery of PSII quantum yield. Complete recovery can occur when the physiological processes that were downregulated during stress, but without damage of the underlying tissue or supply pathways, were simply reactivated (Ruehr et al. 2019). In non-hairy stems, sustained heat-induced photoinhibition during poststress recovery was apparent (Fig. 6), which might indicate irreparable damages to the chloroplast structure and function (Curtis et al. 2014; Guha et al. 2018). Heat-induced decline in maximum PSII quantum yield is known to correspond to inhibition of both the Calvin cycle and electron transport processes, with sustained suppression of $F_{v} / F_{m}$ suggesting irreversible damage to the photosynthetic apparatus (Haldimann and Feller 2004). In leaves, temperature rises above $40{ }^{\circ} \mathrm{C}$ led to longer lasting or permanent impairment of the photosynthetic apparatus via degradation of Rubisco, damage to PSII and thylakoid membranes (Hüve et al. 2011; Teskey et al. 2015). Post-stress recovery is closely linked to repair of photosynthetic and metabolic processes (Ameye et al. 2012; Duarte et al. 2016), which might be different among the tested oak species. The difference in post-stress recovery of $\mathrm{PS}_{\text {cort }}$ among species could also reflect differences among species D1 protein turnover rates (degradation and de novo synthesis of the D1 protein) and subsequent recovery of the photochemical yield of PSII (Aro et al. 1994).

Curtis et al. (2014) found, that species with a higher thermal tolerance exhibited less long-term foliar damage and higher rates of recovery from heat stress than species with lower thermal tolerance. The better recovery capacity of $\mathrm{PS}_{\text {cort }}$ of Mediterranean holm oak as compared to temperate common oak supports the hypothesis that oak species from warmer environments might have a higher resilience of corticular photosynthesis against heat-stress. This is in agreement with a study of Cunningham and Read (2006) on temperate and tropical evergreen trees. They found a greater tolerance of high-temperature stress in species from warmer origin, while Daas et al. (2008) reported that thermal tolerance of PSII in leaves was not more distinct in oak species from warmer Mediterranean regions compared with those from cooler European origin.

A further aspect is the different capacity of leaves and stems to utilize transpirational cooling to avoid or minimize heat stress. In some plants, leaf stomata remain open at high temperature even so photosynthesis is significantly reduced and vapor pressure 
deficit (VPD) is very low (Schulze et al. 1973; Ameye et al. 2012), which seems to be a strategy that uses transpirational cooling of the leaf to avoid hightemperature stress. Stems do not have this capacity due to the anti-transpirant function of the outer bark. Transpiration of young stems was found to be rather small as compared to the transpiration of leaves (stem/ leaf like 1/5-1/20). A characteristic that was mainly attributable to the lower peridermal conductance of water and $\mathrm{CO}_{2}$, which made up only $8-28 \%$ of stomatal conductance (Wittmann and Pfanz 2008).

Concluding, chlorophyll fluorescence measurements of this study revealed that stem hairs play a physiologically significant role in modulating the stem energy balance due to a close interaction between optical characteristics of hairy bark and stem physiological processes.

Acknowledgements The authors acknowledge Christa Kosch from the Laboratory of Applied Botany and the gardeners (Monika Fillippek, Tina Gohlke, Malte Vollmer, Hartmut Ludewig) from the Botanical Garden of the University Duisburg-Essen for their enthusiastic technical and horticultural support.

Author contributions CW: conception of the study; performance of the research; data analysis and interpretation; writing of the manuscript. BK: performance of the research; data analysis. FR: performance of the research; data analysis. HP: data interpretation, writing and proofreading of the manuscript.

Funding Open Access funding enabled and organized by Projekt DEAL.

Open Access This article is licensed under a Creative Commons Attribution 4.0 International License, which permits use, sharing, adaptation, distribution and reproduction in any medium or format, as long as you give appropriate credit to the original author(s) and the source, provide a link to the Creative Commons licence, and indicate if changes were made. The images or other third party material in this article are included in the article's Creative Commons licence, unless indicated otherwise in a credit line to the material. If material is not included in the article's Creative Commons licence and your intended use is not permitted by statutory regulation or exceeds the permitted use, you will need to obtain permission directly from the copyright holder. To view a copy of this licence, visit http://creativecommons.org/licenses/by/4.0/.

\section{References}

Ameye M, Wertin TM, Bauweraerts I, McGuire MA, Teskey RO, Steppe K (2012) The effect of induced heat waves on
Pinus taeda and Quercus rubra seedlings in ambient and elevated $\mathrm{CO}_{2}$ atmospheres. New Phytol 196:448-461

Aro EM, McCaffery S, Anderson JM (1994) Recovery from photoinhibition in peas (Pisum sativum L.) acclimated to varying growth irradiances (role of D1 protein turnover). Plant Physiol 104:1033-1041

Ávila E, Herrera A, Tezara W (2014) Contribution of stem $\mathrm{CO}_{2}$ fixation to whole-plant carbon balance in nonsucculent species. Photosynthetica 52:3-15

Bauweraerts I, Ameye M, Wertin TM, McGuire MA, Teskey RO, Steppe K (2014) Water availability is the decisive factor for the growth of two tree species in the occurrence of consecutive heat waves. Agric For Meteorol 189-190:19-29

Berry J, Bjorkman O (1980) Photosynthetic response and adaptation to temperature in higher plants. Annu Rev Plant Physiol Plant Mol Biol 31:491-543

Berveiller D, Kierzkowski D, Damesin C (2007) Interspecific variability of stem photosynthesis among tree species. Tree Physiol 27:53-61

Bloemen J, McGuire MA, Aubrey DP, Teskey RO, Steppe K (2013) Transport of root-respired $\mathrm{CO}_{2}$ via the transpiration stream affects aboveground carbon assimilation and $\mathrm{CO}_{2}$ efflux in trees. New Phytol 197(2):555-565

Bonfil C, Cortés P, Espelta JM, Retana J (2004) The role of disturbance in the co-existence of the evergreen Quercus ilex and the deciduous Quercus cerrioides. J Veg Sci 15:423-430

Brando PM, Nepstad DC, Balch JK, Bolker B, Christman MC, Coe M, Putz FE (2012) Fire-induced tree mortality in a neotropical forest: the roles of bark traits, tree size, wood density and fire behavior. Glob Change Biol 18:630-641

Cernusak LA, Cheesman AW (2015) The benefits of recycling: how photosynthetic bark can increase drought tolerance. New Phytol 208:995-997

Cunningham SC, Read J (2006) Foliar temperature tolerance of temperate and tropical evergreen rain forest trees of Australia. Tree Physiol 26:1435-1443

Curtis EM, Knight CA, Petrou K, Leigh A (2014) A comparative analysis of photosynthetic recovery from thermal stress: a desert plant case study. Oecologia 175:1051-1061

Daas C, Montpied P, Hanchi B, Dreyer E (2008) Responses of photosynthesis to high temperatures in oak saplings assessed by chlorophyll-a fluorescence: inter-specific diversity and temperature-induced plasticity. Ann For Sci 65:304-306

Damesin C (2003) Respiration and photosynthesis characteristics of current-year stems of Fagus sylvatica: from the seasonal pattern to an estimation over the year. New Phytol 158:465-475

Demmig-Adams B, Moeller D, Logan B, Adams W (1998) Positive correlation between levels of retained zeaxanthin + antheraxanthin and degree of photoinhibition in shade leaves of Shefflera arboricola. Planta 205:367-374

Drake JE, Tjoelker MG, Varhammer A, Medlyn BE, Reich PB, Leigh A, Pfautsch S, Blackman CJ, Lopez R, Aspinwall MJ, Crous KY, Duursma RA, Kumarathunge D, De Kauwe MG, Jiang M, Nicotra AB, Tissue DT, Choat B, Atkin OW, Barton CVM (2017) Trees tolerate an extreme heatwave via sustained transpirational cooling and increased leaf thermal tolerance. Glob Change Biol 24:2390-2402 
Dreyer E, Le Roux X, Montpied P, Daudet FA, Masson F (2001) Temperature response of leaf photosynthetic capacity in seedlings from seven temperate tree species. Tree Physiol 21:223-232

Duarte AG, Katata G, Hoshika Y, Hossain M, Kreuzwieser J, Arneth A, Ruehr NK (2016) Immediate and potential longterm effects of consecutive heat waves on the photosynthetic performance and water balance in Douglas-fir. J Plant Physiol 205:57-66

Ehleringer JR (1984) Ecology and ecophysiology of leaf pubescence in North American desert plants. In: Rodriguez E, Healey PL, Mehta I (eds) Biology and chemistry of plant trichomes. Plenum Press, New York, pp 113-132

Ehleringer JR, Björkman O (1978) Pubescence and leaf spectral characteristics in a desert shrub Encelia farinosa. Oecologia 36:151-162

Ehleringer JR, Mooney HA (1978) Leaf hairs: effects on physiological activity and adaptive value to a desert shrub. Oecologia 37:183-200

Ehleringer JR, Björkman O, Mooney HA (1976) Leaf pubescence: effects on absorptance and photosynthesis in a desert shrub. Science 192:376-377

Genty B, Briantais JM, Baker NR (1989) The relationship between the quantum yield of photosynthetic electron transport and quenching of chlorophyll fluorescence. Biochem Biophys Acta 990:87-92

Ghouil H, Montpied P, Epron D, Ksontini M, Hanchi B, Dryer E (2003) Thermal optima of photosynthetic functions and thermostability of photochemistry in cork oak seedlings. Tree Physiol 23:1031-1039

Gimeno TE, Pias B, Lemos-Filho JP, Valladares F (2008) Plasticity and stress tolerance override local adaption in the responses of Mediterranean holm oak seedlings to drought and cold. Tree Physiol 29:87-98

Guha A, Han J, Cummings C, McLennan D, Warren J (2018) Differential ecophysiological responses and resilience to heat events in four co-occuring temperate tree species. Environ Res Lett 13:65008. https://doi.org/10.1088/17489326/aabcd8

Haldimann P, Feller U (2004) Inhibition of photosynthesis by high temperature in oak (Quercus pubescencs L.) leaves grown under natural conditions closely correlates with a reversible heat-dependent reduction of the activation state of ribulose-1,5-bisphosphate carboxylase/oxygenase. Plant Cell Environ 27:1169-1183

Havaux M, Tardy F, Ravenel J, Chanu D, Parot P (1996) Thylakoid membrane stability to heat stress studied by flash spectroscopic measuremnets of the electrochromic shift in intact potato leaves: influence of the xanthophyll content. Plant Cell Environ 19:1359-1368

Hüve K, Bichele I, Rasulov B, Niinemets Ü (2011) When it is too hot for photosynthesis: heat-induced instability of photosynthesis in relation to respiratory burst, cell permeability changes and $\mathrm{H}_{2} \mathrm{O}_{2}$ formation. Plant Cell Environ 34:113-126

Karabourniotis G, Bornman JF (1999) Penetration of UV-A, UV-B and blue light through the leaf trichome layers of two xeromorphic plants, olive and oak, measured by optical fibre microprobes. Physiol Plant 105:655-661

Lichtenthaler HK, Buschmann C, Knapp M (2005) How to correctly determine the different chlorophyll fluorescence parameters and the chlorophyll fluorescence ratio $\mathrm{R}_{\mathrm{FD}}$ of leaves with the PAM fluorometer. Photosynthetica 43(3):379-393

Loram-Lourenco L, Farnese FDS, Sousa LFD, Alves RDFB, Andrade MCPD, Almeida SEDS, Moura MDF, Costa AC, Silva FG, Galmes J, Cochard H, Franco AC, MenezesSilva PE (2020) A structure shaped by fire, but also water: ecological consequences of the variability in bark properties across 31 species from the Brazilian Cerrado. Front Plant Sci 10:1718

Marchand FL, Mertens S, Kockelbergh F, Beyens L, Nijs I (2005) Performance of high arctic tundra plants improved during but deteriorated after exposure to a simulated extreme temperature event. Glob Change Biol 11:2078-2089

Marchand FL, Kockelbergh F, van de Vijver B, Beyens L, Nijs I (2006) Are heat and cold resistance of arctic species affected by successive extreme temperature events? New Phytol 170:291-300

Markesteijn L, Poorter L, Bongers F, Paz H, Sack L (2011) Hydraulics and life history of tropical dry forest tree species: coordination of species drought and shade tolerance. New Phytol 191:480-495

Martínez-Ferri E, Manrique E, Valladares F, Balaguer L (2004) Winter photoinhibition in the field involves different processes in four co-occurring Mediterranean tree species. Tree Physiol 24:981-990

Maxwell K, Johnson GN (2000) Chlorophyll fluorescence-a practical guide. J Expp Bot 51:659-668

Medlyn BE, Dreyer E, Ellsworth D, Forstreuter M, Harley PC, Kirschbaum MUF, Le Roux X, Montpied P, Strassemeyer J, Walcroft A, Wang K, Loustau D (2002) Temperature response of parameters of a biochemically based model of photosynthesis. II. A review of experimental data. Plant Cell Environ 25:1167-1179

Meinzer F, Goldstein G (1985) Some consequences of leaf pubescence in the Andean giant rosette plant Espeletia timotensis. Ecology 66:512-520

Niinemets U, Oja V, Kull O (1999) Shape of leaf photosynthetic electron transport versus temperature response curve is not constant along canopy light gradients in temperate deciduous trees. Plant Cell Environ 22:1497-1514

O'Sullivan OS, Heskel MA, Reich PB, Tjoelker MG, Weerasinghe LK, Penillard A, Zhu L, Egerton JJG, Bloomfield KJ, Creek D, Bahar NHA, Griffin KL, Hurry V, Meir P, Turnbull MH, Atkin OK (2017) Thermal limits of leaf metabolism across biomes. Glob Change Biol 23:209-223

Peñuelas J, Llusià J (2002) Linking photorespiration, monoterpenes and thermotolerance in Quercus. New Phytol 155:227-237

Pfanz H (1999) Photosynthetic performance of twigs and stems of trees with and without stress. Phyton 39:29-33

Pfanz H, Aschan G, Langenfeld-Heyser R, Wittmann C, Loose M (2002) Ecology and ecophysiology of tree stems: corticular and wood photosynthesis. Naturwissenschaften 89:147-162

Poorter L, Mcneil A, Hurtado VH, Prinz HHT, Putz FH (2014) Bark traits and life-history strategies of tropical dry- and moist forest trees. Funct Ecol 28:232-242

Powers EM, Marshall JD (2011) Pulse labeling of dissolved $13 \mathrm{C}$-carbonate into tree xylem: developing a new method 
to determine the fate of recently fixed photosynthate. Rapid Commun Mass Spectrom 25:33-40

Rosell JA (2016) Bark thickness across the angiosperms: more than just fire. New Phytol 211:90-102

Ruehr NK, Grote R, Mayr S, Arneth A (2019) Beyond the extreme: recovery of carbon and water relations in woody plants following heat and drought stress. Tree Physiol 39:1285-1299

Salvucci ME, Crafts-Brandner SJ (2004) Relationship between the heat tolerance of photosynthesis and the thermal stability of rubisco activase in plants from contrasting thermal environments. Plant Physiol 134:1460-1470

Schulze E-D, Lange OL, Kappen L, Bushbom U, Evenari M (1973) Stomatal responses to changing temperature at increasing water stress. Planta 110:29-42

Skaltsa H, Verykokidou E, Harvala C, Karabourniotis G, Manetas Y (1994) UV-B protective potential and flavonoid content of leaf hairs of Quercus ilex. Phytochemistry 37:987-990

Skelton RP, Midgley JJ, Nyaga JM, Johnson SD, Cramer MD (2012) Is leaf pubescence of Cape Proteaceae a xeromophic or radiation-protective trait? Aust $\mathrm{J}$ Bot 60:104-113

Teskey RO, Saveyn A, Steppe K, McGuire MA (2008) Origin, fate and significance of $\mathrm{CO}_{2}$ in tree stems. New Phytol 177:17-32

Teskey R, Wertin T, Bauweraerts I, Ameye M, McGuire M, Steppe K (2015) Responses of tree species to heat waves and extreme heat events. Plant Cell Environ 38:1699-1712

Valladares F, Zaragoza-Castells J, Sánchez-Gómez D, Matesanz S, Alonso B, Portsmuth A, Delgado A, Atkin OK (2008) Is shade beneficial for Mediterranean shrubs experiencing periods of extreme drought and late-winter frosts? Ann Bot 102(6):923-933

Vines R (1968) Heat transfer trough bark, and the resistance of trees to fire. Aust J Bot 16:499-514
Wahid A, Gelani S, Ashraf M, Foolad MR (2007) Heat tolerance in plants: an overview. Environ Exp Bot 61:199-223

Wellburn AR (1994) The spectral determination of chlorophylls $\mathrm{a}$ and $\mathrm{b}$, as well as total carotenoids, using various solvents with spectrophotometers of different resolution. J Plant Physiol 144:307-313

Williamson GB, Wiemann MC (2010) Measuring wood specific gravity...correctly. Am J Bot 97:519-524

Wittmann C, Pfanz H (2007) Temperature dependency of bark photosynthesis in beech (Fagus sylvatica L.) and birch (Betula pendula Roth.) trees. J Exp Bot 58:4293-4306

Wittmann C, Pfanz H (2008) Antitranspirant functions of stem periderms and their influence on corticular photosynthesis under drought stress. Trees 22:187-196

Wittmann C, Pfanz H (2015) Bark and woody tissue photosynthesis: a means to avoid hypoxia or anoxia in developing stem tissues. Funct Plant Biol 41(9):940-953

Wittmann C, Aschan G, Pfanz H (2001) Leaf and twig photosynthesis of young beech (Fagus sylvatica) and aspen (Populus tremula) trees grown under different light intensity regimes. Basic Appl Ecol 2:145-154

Wittmann C, Pfanz H, Loreto F, Centritto M, Pietrini F, Alessio G (2006) Light-induced reduction of carbon release from branches of birch trees: corticular photosynthesis, photorespiration or inhibition of mitochondrial respiration? Plant Cell Environ 29(6):1149-1158

Yao Y, Luo Y, Huang J, Zhao Z (2013) Comparison of monthly temperature extremes simulated by CMIP3 and CMIP5 models. J Climate 26:7692-7707

Publisher's Note Springer Nature remains neutral with regard to jurisdictional claims in published maps and institutional affiliations. 